\title{
IMPLEMENTASI PARIWISATA BERKELANJUTAN DI EDUWISATA ENGGANG GADING
}

\author{
Khoiul Fajri ${ }^{1}$ \\ Sekolah Tinggi Ilmu Ekonomi Pariwisata Yapari \\ Khoirul.fajri@yahoo.com \\ Taufiq Hidayat ${ }^{2}$ \\ Sekolah Tinggi Ilmu Ekonomi Pariwisata Yapari \\ Taufiqhi7912@gmail.com \\ Nelissa Lenjau ${ }^{3}$ \\ Sekolah Tinggi Ilmu Ekonomi Pariwisata Yapari \\ Nelissa.lenjau09@gmail.com
}

\begin{abstract}
As a new development paradigm, sustainable tourism is believed to be able to provide a multiplier effect or multiple impacts. The implementation of sustainable tourism is believed to be able to bring progress to Indonesian tourism. This encourages the adoption of sustainable tourism widely, even in areas with low tourism intensity. The research which was held at Enggang Gading Samarinda East Kalimantn, Tourism Center aims to see the implementation of sustainable tourism in the environmental, socio-cultural, and economic fields. The qualitative approach used in this research is the percentage descriptive analysis technique, where the data collection process is carried out through open and in-depth interviews, participatory observation, and documentation study. The results showed that Enggang Gading tourism had implemented activities guided by the principles of sustainable tourism, especially in the application of 3 (three) aspects, namely; physical environmental aspects, socio-cultural aspects, and economic aspects. From the results of an assessment of the results of the informants' answers in each aspect, it shows that the implementation of sustainable tourism on average reaches a score of $67 \%$ which means it is in the sufficient category. However, the stakeholders in the Enggang Gading Tourism Edu tour need to increase efforts to implement the environmental, socio-cultural, and economic aspects that are its components so that the percentage of sustainable tourism achievement in the Enggang Gading Edu tour can increase in the future.
\end{abstract}

Key words: Implementation, sustainable tourism, edutourism

\begin{abstract}
ABSTRAK
Sebagai paradigma pembangunan yang baru, pariwisata berkelanjutan (sustainable tourism) diyakini mampu memberikan multiplier effect atau dampak ganda. Penerapan sustainable tourism diyakini dapat membawa kemajuan bagi pariwisata Indonesia. Hal tersebut tersebut mendorong penerapan pariwisata berkelanjutan secara luas, bahkan di kawasan-kawasan dengan intensitas pariwisata yang rendah. Penelitian yang diadakan di Eduwisata Enggang Gading Samarinda Kalimantan timur bertujuan untuk melihat implementasi pariwisata berkelanjutan di bidang lingkungan, sosial budaya, dan ekonomi. Pendekatan kualitatif
\end{abstract}


digunakan dalam penelitian ini dengan teknik analisis deskriptif persentase yang proses pengumpulan datanya dilakukan melalui wawancara yang bersifat terbuka dan mendalam, observasi partisipatif, dan studi dokumentasi. Hasil penelitian menunjukkan bahwa Eduwisata Enggang Gading telah menerapkan kegiatan yang berpedoman pada prinsip-prinsip pariwisata berkelanjutan khususnya dalam penerapan 3 (tiga) aspek yaitu; aspek lingkungan fisik, aspel sosial budaya dan aspek ekonomi. Dari hasil penilaian terhadap hasil jawaban informan pada masing-masing aspek menunjukkan bahwa penerapan pariwisata berkelanjutan rata-rata mencapai skor $67 \%$ yang berarti masuk kedalam kategori cukup. Namun demikian para pemangku kepentingan di Eduwisata Enggang Gading perlu meningkatkan upaya penerapan terhadap aspek lingkungan, sosial budaya, dan ekonomi yang menjadi komponenkomponennya sehingga persentase pencapaian pariwisata berkelanjutan di Eduwisata Enggang Gading dapat meningkat di kemudian hari.

Kata kunci: Implementasi, pariwisata berkelanjutan, eduwisata

\section{PENDAHULUAN}

Sebagai paradigma pembangunan yang baru, pariwisata berkelanjutan mulai diterapkan di berbagai provinsi di Indonesia. Menurut Tenaga Ahli Menteri Bidang Pembangunan Pariwisata Berkelanjutan Valerina Daniel—sesuai kutipan berita CNN Indonesia edisi Juli 2018 - pariwisata berkelanjutan di Indonesia mengacu pada tiga prinsip, yaitu people, planet, dan prosperity. Berita Tribun News edisi Desember 2018 turut mencatat bahwa pada tahun 2018, beberapa destinasi wisata nasional mendapatkan penghargaan Indonesia Sustainable Tourism Award (ISTA) di berbagai kategori, yaitu pemanfaatan ekonomi, sosial budaya, dan lingkungan. Hal tersebut menunjukkan bahwa pariwisata berkelanjutan merupakan sistem yang memberikan multiplier effect atau dampak ganda bagi perekonomian suatu daerah dan masyarakat sekitar, secara langsung dapat menciptakan peluang pekerjaan bagi masyarakat lokal sehingga dapat meningkatkan kesejahteraan dan dapat meningkatkan perekonomian daerah.

Di Indonesia, salah satu provinsi yang belum menerapkan pariwisata berkelanjutan secara merata adalah Kalimantan Timur, sebagaimana penjelasan kepala Badan Perencanaan Daerah Kalimantan timur pada seminar online yang diselenggarakan oleh Unit Layanan Strategis Pusat Kajian Pengembangan dan Penataan Ruang Universitas Mulawarman, 13 Agustus 2020; "Meskipun Kalimantan Timur memiliki berbagai objek wisata yang menarik, namun masih diperlukan kerja keras dari semua stakeholder dan dukungan masyarakat agar pariwisata di Kalimantan Timur dapat menjadi destinasi prioritas nasional dan berdaya saing”.

Sebagai provinsi dengan lahan seluas $211.440 \mathrm{~km} 2$, berdasarkan data Asisten Deputi Pengembangan Destinasi Regional II Kementrian Pariwisata tahun 2011, Kalimantan Timur hanya terdapat dua Destinasi Pariwisata Nasional (DPN), enam Kawasan Pengembangan Pariwisata Nasional (KPPN), dan tiga Kawasan Strategis Pariwisata Nasional (KSPN). Sebagai Ibu Kota Provinsi Kalimantan Timur, Kota Samarinda mulai mengembangkan pembangunan pariwisata. Hal itu terlihat dari pemetaan beberapa daya Tarik wisata baru seperti Pulau Kumala, Jungle Water World, dan Taman Rekreasi Lembah Hijau. Namun daya tarik wisata tersebut lebih mengarah pada konsep modern sehingga kurang memperhatikan aspek keberlanjutan alam, budaya, dan ekonomi masyarakat.

Kota Samarinda dihadapkan pada persoalan lingkungan yang cukup memprihatinkan, hal tesebut sebagai dampak dari berbagai aktivitas industri. Menurut berita Kaltim Kece edisi Juli 2019, Kota Samarinda memiliki izin pertambangan seluas 27.438 hektare dan izin perkebunan seluas 3.000 hektare. Kegiatan industri tersebut sangat berdampak pada kondisi 
lingkungan secara luas. Berita terkini banyak yang memberitakan terkait banjir yang melanda Kota Samarinda. Hal tersebut menurut sejumlah pemerhati lingkungan setempat diduga akibat adanya aktivitas tambang batu bara. Situasi tersebut diperburuk oleh kegiatan sejumlah usaha perkebunan yang tidak bertanggung jawab.

Di samping masalah lingkungan, masyarakat Kota Samarinda dihadapkan pada persoalan lain dampak dari aktivitas industri. Banyak usaha mengadakan perluasan lahan yang turut memangkas hutan-hutan adat. Dengan menipisnya sumber penghidupan, sebagian besar warga terpaksa bekerja sebagai buruh perkebunan atau kuli tambang. Bagaimana pun, masalah lingkungan dan ekonomi bukan hanya persoalan yang dihadapi masyarakat. Sebagai kaum penjunjung adat, budaya masyarakat Dayak khususnya Dayak Kenyah kerap dinilai bertentangan dengan prinsip-prinsip kelestarian lingkungan. Dalam berbagai festival budaya contohnya, masyarakat Dayak Kenyah kerap mengenakan atribut berupa bulu-bulu maupun paruh satwa rangkong (enggang). Kebiasaan tersebut telah mendapat kritikan dari sejumlah pihak. Dalam berita Sinar Harapan edisi Juni 2016, mantan gubernur Kalbar Cornelis, menyatakan pendapatnya bahwa pemakaian bulu-bulu enggang harus segera dihentikan karena unggas tersebut termasuk satwa yang dilindungi.

Hal tersebut sulit diubah karena merupakan kebiasaan atau tradisi masyarakat Dayak sejak dulu. Pada masa lalu, masyarakat Dayak menjunjung kebanggaannya dengan mengenakan berbagai atribut yang berasal dari satwa enggang. Kini, pemakaian atribut-atribut tersebut mulai diperdebatkan terkait eksistensi satwa endemik yang terancam punah. Dengan demikian, budaya yang seharusnya mencerminkan kearifan dan tata kehidupan yang seimbang, justru tercermin dalam bentuk sebaliknya. Alhasil, wisatawan tidak melihat wujud nyata dari hal-hal yang dipentaskan di atas panggung dan mulai menilai Dayak Kenyah sebagai komunitas yang turut merusak alam.

Menurut Sunaryo (2013:42), pariwisata berkelanjutan dapat menjadi sarana yang mewujudkan hubungan positif antara kepariwisataan dan lingkungan setempat. World Tourism Organization (WTO), turut mencatat bahwa pariwisata berkelanjutan dapat meningkatkan aspek ekonomi, sosial, dan keindahan dengan cara mempertahankan keberadaan lingkungan, keanekaragaman hayati, dan kebudayaan yang berintegritas. (Sustainable tourism development is envisaged as a leading to management of all resources in such a way that economic, social, and aesthetic needs can be fulfilled while maintaining essential ecological processes, biological diversity, and cultural integrity).

Pariwisata berkelanjutan menurut Sunaryo (2013:53-54) terdiri dari tiga dimensi, yaitu keberlanjutan lingkungan fisik, keberlanjutan sosial budaya, dan keberlanjutan secara ekonomi. Terkait aspek-aspek tersebut, World Tourism Organization (2004) menetapkan beberapa hal yang menjadi indikatornya, yaitu: 1. Aspek Keberlanjutan Lingkungan Fisik (Environmental Sustainability), yang mencakup: a) perlindungan terhadap aset lingkungan (protection of valuable natural assets); b) manajemen sumber daya lingkungan (managing natural resources); dan c) minimalisir dampak kegiatan wisata (limiting impacts of tourism activity). 2. Aspek Keberlanjutan Sosial Budaya (Social Sustainability), yang mencakup: a) penyanggaan aset budaya (sustaining cultural assets); b) partisipasi masyarakat (community participation); dan c) interaksi masyarakat (community attitudes). 3. Aspek Keberlanjutan Ekonomi (Economic Sustainability), yang mencakup: a) ketenagakerjaan (employment); dan b) kebijakan upah (wage policies).

Sebagai sebuah destinasi baru, Eduwisata Enggang Gading tidak memelopori upayaupaya besar seperti revitalisasi hutan atau kampanye berisi perlawanan terhadap sektor industri. 
Sebaliknya, melalui rekreasi, Eduwisata Enggang Gading berusaha menyampaikan pesan tentang pentingnya menjaga alam dan dengan demikian turut ambil bagian dalam menyelamatkan hutan-hutan dan sumber daya yang masih tersisa. Dalam kegiatannya, Eduwisata Enggang Gading mengangkat berbagai kearifan lokal Dayak Kenyah seperti seni musik tradisional, seni mengukir, dan seni berladang. Hal-hal tersebut diadakan bukan hanya untuk melestarikan kebudayaan, tetapi juga memberdayakan masyarakat secara maksimal. Adapun penelitian yang diadakan di Eduwisata Enggang Gading bertujuan untuk melihat implementasi pariwisata berkelanjutan di bidang lingkungan, sosial budaya, dan ekonomi.

\section{METODOLOGI}

Desain penelitian ini menggunakan metode penelitian kualitatif deskriptif dengan teknik observasi partisipatif. Dengan metode kualitatif deskrisptif yang berusaha menggambarkan suatu gejala sosial. Peneliti menggunakan desain penelitian ini karena peneliti ingin mengetahui dan memberikan gambaran secara jelas mengenai implementasi pariwisata berkelanjutan di Eduwisata Enggang Gading Puncak Samarinda.

Teknik pengumpulan data dalam penelitian ini meliputi wawancara, observasi lapangan, dan studi dokumentasi. Wawancara dilakukan dengan sejumlah pengelola Eduwisata Enggang Gading, tokoh masyarakat, aparat pemerintah setempat, dan perwakilan komunitas peduli Enggang Gading untuk memberikan kejelasan dan kesesuaian terhadap data dan informasi yang diperlukan berjumlah 8 orang. Observasi lapangan yaitu melihat kegiatan yang dilakukan di lokasi penelitian dari aspek penerapan program kerja dan kegiatan daya tarik wisata. Dokumentasi adalah pengumpulan dokumen baik yang berbentuk tulisan, gambar (foto), maupun karya lainnya baik dokumen yang dipublikasikan oleh perorangan yang mewakili komunitas dan dapat dipertanggungjawabkan ataupun dari instansi terkait.

Untuk mempermudah peneliti dalam melakukan pengumpulan data, maka digunakan instrumen pendukung yaitu pedoman wawancara, pedoman observasi, dan pedoman dokumentasi seperti yang dijelaskan pada tabel 1 berikut.

Tabel 1. Kisi-kisi Pedoman Wawancara

\begin{tabular}{|c|c|c|}
\hline NO. & SUB VARIABEL & INDIKATOR \\
\hline 1. & Aspek Lingkungan Fisik & $\begin{array}{l}\text { a. Kegiatan dalam pengorganisasian } \\
\text { b. Intrepretasi dalam pengelolaan dengan } \\
\text { berbagai program kerja. } \\
\text { c. Aplikasi atau penerapan dalam program- } \\
\text { program kerja. }\end{array}$ \\
\hline 2. & Aspek Sosial Budaya & $\begin{array}{l}\text { a. Kegiatan dalam pengorganisasian } \\
\text { b. Intrepretasi dalam pengelolaan dengan } \\
\text { berbagai program kerja. } \\
\text { c. Aplikasi atau penerapan dalam program- } \\
\text { program kerja }\end{array}$ \\
\hline 3. & Aspek Ekonomi & $\begin{array}{l}\text { a. Kegiatan dalam pengorganisasian } \\
\text { b. Intrepretasi dalam pengelolaan dengan } \\
\text { berbagai program kerja. } \\
\text { c. Aplikasi atau penerapan dalam program- } \\
\text { program kerja }\end{array}$ \\
\hline
\end{tabular}


Tabel 2. Kisi-kisi Pedoman Observasi

\begin{tabular}{|c|c|c|}
\hline NO. & ASPEK & INDIKATOR \\
\hline 1. & Tempat dan Sarana Prasarana & $\begin{array}{l}\text { a. Tempat yang digunakan untuk kegiatan } \\
\text { atau pengorganisasian, intrepretasi } \\
\text { pengelolaan program kerja. } \\
\text { b. Sarana dan prasarana untuk kegiatan atau } \\
\text { pengorganisasian, intrepretasi } \\
\text { pengelolaan program kerja. }\end{array}$ \\
\hline 2. & Pelaksana & $\begin{array}{l}\text { a. Tokoh dan Masyarakat Enggang Gading } \\
\text { b. Pemerintah setempat }\end{array}$ \\
\hline 3. & Kegiatan & $\begin{array}{ll}\text { a. Kegiatan Atraksi Wisata } \\
\text { b. Kegiatan Pelaksanaan Program Kerja }\end{array}$ \\
\hline
\end{tabular}

Tabel 3. Kisi-kisi Pedoman Dokumentasi

\begin{tabular}{|c|l|ll|}
\hline NO. & \multicolumn{2}{|c|}{ ASPEK } & \multicolumn{2}{c|}{ INDIKATOR } \\
\hline 1. & $\begin{array}{l}\text { Implementasi Program Kerja } \\
\text { dalam pemenuhan pariwisata } \\
\text { berkelanjutan di Enggang } \\
\text { Gading }\end{array}$ & $\begin{array}{l}\text { a. } \\
\text { Dokumen rencana kerja pelaksanaan } \\
\text { pariwisata berkelanjutan } \\
\text { Dokumen kegiatan atraksi wisata dan } \\
\text { pelaksanaan program kerja parwisata } \\
\text { berkelanjutan }\end{array}$ \\
\hline
\end{tabular}

Metode dan teknik analisis data yang digunakan adalah teknik analisis data deskriptif persentase yaitu teknik analisis data yang digunakan untuk kegiatan pengolahan data dengan cara memberikan deskripsi dan memberikan gambaran pada setiap sumber data penelitian yang telah dikumpulkan oleh seorang peneliti di lapangan. Teknik analisis data deskriptif biasanya digunakan dalam penelitian yang bersifat kualitatif. Penyajian data teknik analisis data deskriptif biasanya disajikan dalam bentuk tabel, grafik, frekuensi, persentase, diagram, dan lain sebagainya.

Dalam penelitian ini data akan ditampilkan dalam bentuk persentase angka. Untuk memperoleh frekuensi relatif/angka persenan maka dilakukan perhitungan dengan menggunakan rumus sebagai berikut (Sudijono, 2012:43):

$$
\mathrm{P}=|f| N \times 100 \%
$$

Keterangan:

$\mathrm{f}=$ Frekuensi yang sedang dicari presentasenya

$\mathrm{N}=$ Jumlah frekuensi/banyaknya individu 


\section{$\mathrm{P}=$ Angka persentase}

Pemaparan hasil pengamatan dan wawancara yang kemudian dilakukan perhitungan secara persentase melalui 2 tahap untuk penerapan 3 (tiga) aspek pariwisata berkelanjutan yang sudah mulai diterapkan.

1. Persentase untuk komponen-komponen yang diterapkan dari total komponen yang ada dalam 1 (satu) aspek pariwisata berkelanjutan.

Persentase $=\underline{\text { Komponen yang diterapkan }} \times 100 \%$ Jumlah Komponen Total

2. Persentase untuk jumlah aspek pariwisata berkelanjutan yang telah diterapkan dari 3 (tiga) aspek pariwisata berkelanjutan sesuai tinjauan pustaka yaitu keberlanjutan lingkungan fisik, keberlanjutan sosial budaya, dan keberlanjutan ekonomi. .

$$
\text { Persentase }=\underset{\text { Jumlah total aspek pariwisata berkelanjutan }}{\text { Total nilai aspek yang diterapkan }} \times
$$

Berdasarkan rumus diatas maka akan diperoleh kategori berdasarkan persentase sebagai berikut:

Tabel 4. Interval nilai persentase

\begin{tabular}{|c|c|}
\hline Interval Skor (\%) & Kategori \\
\hline $81-100$ & Sangat Baik \\
\hline $66-80$ & Baik \\
\hline $56-65$ & Cukup \\
\hline $41-55$ & Kurang \\
\hline $25-40$ & Tidak Baik \\
\hline
\end{tabular}

(Sudijono, 2012:43):

\section{Hasil dan Pembahasan}

Puncak Samarinda adalah sebuah kawasan yang baru-baru ini dicanangkan sebagai salah satu Kawasan Strategis Pariwisata (KSP) Provinsi Kalimantan Timur tingkat kota. Puncak Samarinda yang terletak di Kelurahan Budaya Pampang, Kecamatan Samarinda Utara tersebut memiliki area seluas 30,84 km2 dan terdiri dari 6 RT. Batas-batas wilayah Puncak Samarinda yaitu Kabupaten Kutai Kartanegara di sebelah utara, Kelurahan Tanah Merah di sebelah selatan, Kelurahan Sempaja Utara di sisi barat, dan Kelurahan Sungai Siring di sisi timur. 
Meski terletak di dataran tinggi $( \pm 400 \mathrm{mdpl})$, Puncak Samarinda memilki suhu ratarata $32^{\circ}$ Celcius karena dekat dengan garis khatulistiwa. Sebagai daerah tujuan wisata (DTW), Puncak Samarinda terdiri dari berbagai destinasi wisata

\section{Gambar 1 | Kawasan Puncak Samarinda}

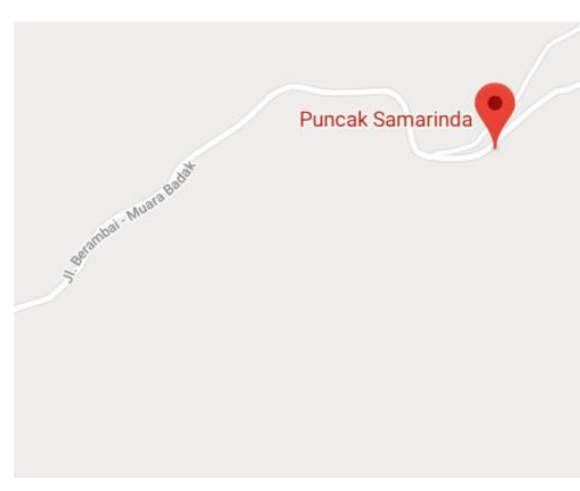

Sumber: Google Maps, 2019

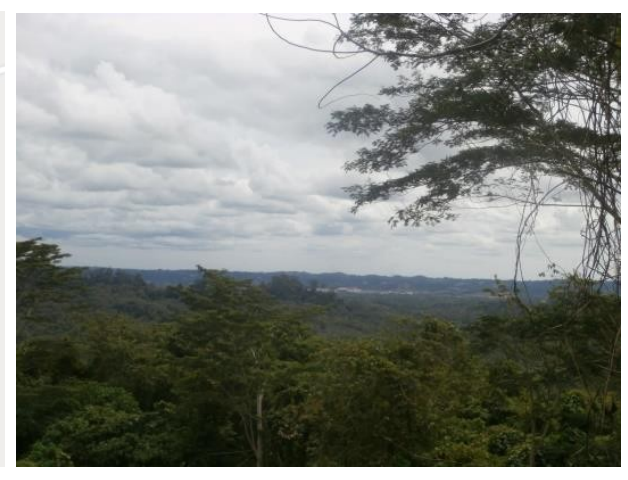

Sumber: Dokumentasi Pribadi, 2019

Gambar 2 | Akses menuju Enggang Gading Samarinda
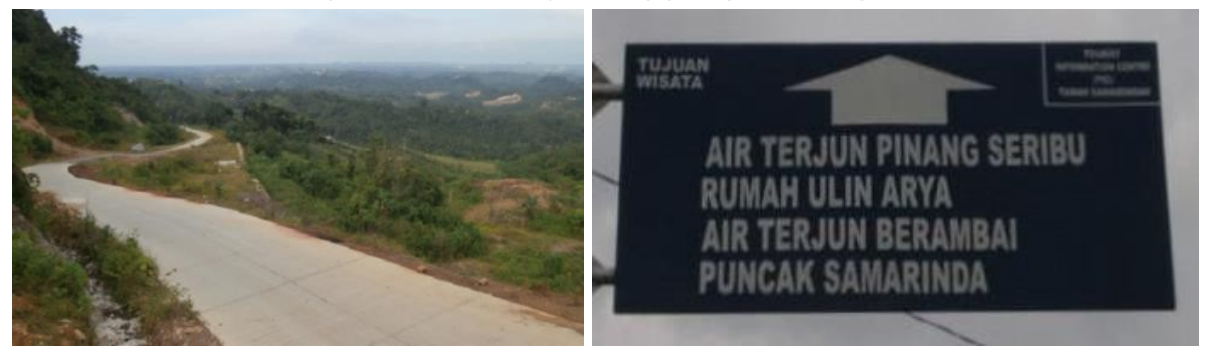

Sumber: Dokumentasi Pribadi, 2019

Eduwisata Enggang Gading adalah salah satu komunitas peduli wisata (KOPEWI) yang diwadahi oleh sebuah perkumpulan bernama Peduli Wisata Enggang Gading Borneo (PWEG). Sebagai salah satu KOPEWI binaan PWEG, Eduwisata Enggang Gading memiliki visi dan misi yang mengarah pada pemberdayaan masyarakat dan konservasi lingkungan, satwa, serta budaya lokal. Eduwisata Enggang Gading merupakan sebuah destinasi wisata yang terletak di RT. 06, Kelurahan Budaya Pampang, Kecamatan Samarinda Utara, Kota Samarinda. Destinasi tersebut memiliki total area seluas 3 hektare dan berjarak sekitar $2 \mathrm{~km}$ dari Air Terjun Berambai yang merupakan destinasi terdekat. Dengan mengoptimalisasi bekas ladang penduduk Dayak, kawasan Eduwisata Enggang Gading terdiri dari hutan dan lahan terbuka.

\section{Atraksi di Eduwisata Enggang Gading}

Tabel 5. Atraksi di Eduwisata Enggang Gading

\begin{tabular}{|c|c|c|}
\hline Atraksi & Deskripsi & Gambar \\
\hline Nature view & $\begin{array}{c}\text { Menyaksikan hamparan ladang dan } \\
\text { hutan dari ketinggian }\end{array}$ \\
\hline
\end{tabular}




\begin{tabular}{|c|c|c|}
\hline Bercocok tanam & $\begin{array}{l}\text { Menanam berbagai jenis bibit } \\
\text { tumbuhan ladang dan tanaman rempah }\end{array}$ & \\
\hline $\begin{array}{l}\text { Memetik hasil } \\
\text { ladang }\end{array}$ & $\begin{array}{l}\text { Memetik buah - buahan yang telah } \\
\text { matang }\end{array}$ & \\
\hline $\begin{array}{c}\text { Pertunjukan } \\
\text { Musik tradisional }\end{array}$ & $\begin{array}{c}\text { Menyaksikan permaianan alat musik } \\
\text { sampeq }\end{array}$ & \\
\hline $\begin{array}{l}\text { Bermain sampeq } \\
\text { (alat musik } \\
\text { tradisional) }\end{array}$ & $\begin{array}{l}\text { Mempelajari teknik dasar permaianan } \\
\text { sampeq }\end{array}$ & \\
\hline $\begin{array}{c}\text { Menyaksikan } \\
\text { proses } \\
\text { pembuatan } \\
\text { kerajinan }\end{array}$ & $\begin{array}{c}\text { Menyaksikan proses pengolahan bahan } \\
\text { baku alami menjadi karya yang bernilai } \\
\text { jual }\end{array}$ & \\
\hline $\begin{array}{l}\text { Membuat } \\
\text { kerajinan }\end{array}$ & $\begin{array}{c}\text { Mempelajari teknik pembuatan } \\
\text { kerajinan }\end{array}$ & \\
\hline $\begin{array}{l}\text { Mengenakan } \\
\text { pakaian dan } \\
\text { atribut tradisional }\end{array}$ & $\begin{array}{l}\text { Berfoto di spot dengan menggunakan } \\
\text { pakaian dan perlengkapan berladang } \\
\text { tradisional }\end{array}$ & \\
\hline Pemung tawai & $\begin{array}{l}\text { Mengikuti rangkaian kegiatan yang } \\
\text { mencakup makan bersaman dan } \\
\text { penyampaian pesan - pesan berharga }\end{array}$ & \\
\hline $\begin{array}{l}\text { Ritual } \\
\text { sembayang }\end{array}$ & $\begin{array}{l}\text { Menyaksikan rangkaian doa syukur } \\
\text { atas pemberian tuhan }\end{array}$ & \\
\hline Forest Trekking & $\begin{array}{l}\text { Mengenali karakteristik setiap } \\
\text { tumbuhan berkayu }\end{array}$ & \\
\hline Menanam pohon & $\begin{array}{l}\text { Menanam berbagai jenis bibit } \\
\text { tumbuhan berkayu }\end{array}$ & \\
\hline
\end{tabular}

Sumber : Hasil Olahan Peneliti, 2019 
Berdasarkan tabel di atas dapat dijelaskan bahwa daya Tarik Eduwisata Enggang Gading adalah sebagai berikut.

Faktor What To Buy, Menurut Ibu Korlina selaku ketua divisi produksi dan logistik, masyarakat di Eduwisata Enggang Gading mulai menawarkan beragam produk wisata kepada pengunjung. Saat ini, kategori produk di Eduwisata Enggang Gading telah mencakup kuliner, hasil ladang, tanaman obat, dan hasil kerajinan tangan

Faktor What To Learn, Melalui kegiatan di Eduwisata Enggang Gading, pengunjung dapat mempelajari berbagai macam pengetahuan dan keterampilan yang baru. Sejauh ini, atraksi what to learn yang disajikan di Eduwisata Enggang Gading meliputi wawasan seputar budaya dan wawasan seputar lingkungan.

Faktor Where To Stay, Untuk memenuhi kebutuhan pengunjung akan akomodasi, pengelola Eduwisata Enggang Gading menyediakan pondok-pondok penginapan dengan harga Rp. $100.000,00$ per malam. Pondok-pondok tersebut dapat memuat empat hingga lima orang dan memiliki fasilitas berupa tikar rotan (lampit), lampu-lampu minyak tanah, teras panggung, dan tungku untuk memasak. Saat ini, pengelola Eduwisata Enggang Gading juga sedang mengadakan proyek pembangunan rumah panjang (umaq panjang). Pengelola Eduwisata Enggang Gading merencanakan agar setiap kamar atau bagian dari rumah panjang tersebut disewakan dengan harga Rp. 75.000,00 per malam.

\section{Implementasi Pariwisata Berkelanjutan di Edukasi Enggang Gading}

1. Aspek Lingkungan Fisik Eduwisata Enggang Gading menerapkan pariwista berkelanjutan dalam aspek lingkungan fisik melalui tiga upaya, yaitu :

a. Pengorganisasian

Dalam tahap pengorganisasian, pengelola Eduswisata Engganng gading merencanakan program Pendidikan Lingkungan Hidup (PPLH) dan kerjasama dengan dinas - dinas lingkungan setempat.

b. Intrepretasi

Untuk memberikan gambaran nyata dilapangan pengelola Eduwisata Enggang Gading menerjemahkan misi Eduwisata Enggang Gadiing yang pertama dalam berbagai bentuk teknis yang sesuai degan kaidah lingkungan fisik.

Tabel 6

Teknis Program Kerja Dalam Aspek Lingkungan Fisik

\begin{tabular}{|c|c|}
\hline Upaya & Petunjuk Teknis \\
\hline \multirow{3}{*}{$\begin{array}{c}\text { Melindungi Aset } \\
\text { Lingkungan }\end{array}$} & Menampilkan fakta seputar hutan dan satwa \\
\cline { 2 - 3 } & Mengadakan sosialisasi seputar lingkungan \\
\cline { 2 - 2 } & $\begin{array}{c}\text { Mengadakan program penanaman } \\
\text { tumbuhan keras }\end{array}$ \\
\cline { 2 - 2 } & $\begin{array}{c}\text { Mengeliminasi pengangguran organ satwa sebagai atribut } \\
\text { budaya }\end{array}$ \\
\hline
\end{tabular}




\begin{tabular}{|c|c|}
\hline \multirow{2}{*}{$\begin{array}{l}\text { Manajemen } \\
\text { Sumber Daya } \\
\text { Lingkungan }\end{array}$} & Mengurangi penggunaan listrik \\
\hline & $\begin{array}{c}\text { Mengelola air, tanah, tumbuhan pangan, dan tumbuhan } \\
\text { keras secara berkelanjutan }\end{array}$ \\
\hline \multirow{3}{*}{$\begin{array}{c}\text { Minimalisir } \\
\text { Dampak Kegiatan } \\
\text { Wisata }\end{array}$} & Mengurangi penggunaan pelastik \\
\hline & Membangun pondok - pondok semi permanen \\
\hline & Menandai bibit tumbuhan \\
\hline
\end{tabular}

Sumber : Hasil Olahan Peneliti, 2019

c. Aplikasi

Eduwisata Enggang Gading merupakan pariwisata berkelanjutan dalam aspek fisik melalui tiga upaya, yaitu :

1). Melindungi Aset Lingkungan, Data-data dan informasi yang diperoleh Peneliti di lapangan menunjukkan bahwa Eduwisata Enggang Gading telah menerapkan upaya perlindungan terhadap aset lingkungan. Menurut World Tourism Organization (WTO), perlindungan terhadap aset lingkungan terdiri dari beberapa komponen, yaitu: 1 . perlindungan terhadap kawasan alami; 2. perlindungan terhadap satwa yang terancam punah; dan 3. penetapan zona konservasi. Upaya perlindungan terhadap aset lingkungan dapat dikatakan telah mencapai $100 \%$ apabila ketiga komponen tersebut terpenuhi. Namun sejauh ini, Eduwisata Enggang baru berhasil menerapkan dua dari tiga komponen, yaitu perlindungan terhadap kawasan alami dan perlindungan terhadap satwa langka secara tidak langsung. Untuk itu, tingkat persentase dari penerapan upaya perlindungan terhadap lingkungan fisik di Eduwisata Enggang Gading, adalah:

$$
\text { Persentase }=\frac{\text { Komponen yang ditetapkan }}{\text { Jumlah Komponen Total }} \text { 100\% }
$$

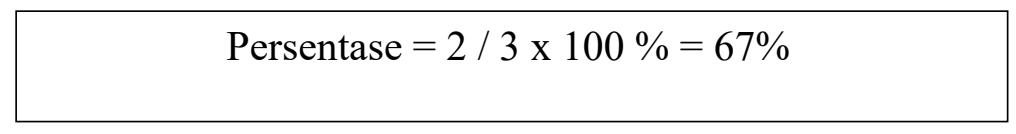

Dengan demikian, Edukasi Enggang Gading telah menerapkan manajemen terhadap sumber daa lingkungan sebesar $67 \%$ sebagai bagian kedua dari pariwisata berkelanjutan di bidang lingkungan fisik.

2). Manajemen Sumber Daya Lingkungan, Menurut Bapak Saperi selaku ketua umum Eduwisata Enggang Gading, bentuk lain dari penerapan pariwisata berkelanjutan di bidang lingkungan adalah manajemen sumber daya alam dan energi. Narasumber menyatakan bahwa dalam kegiatannya, Eduwisata Enggang Gading mengadakan pengelolaan sumber daya alam berupa air, tanah, tumbuhan pangan, dan tumbuhan berkayu; serta sumber daya energi berupa listrik.

$$
\text { Persentase }=\frac{\text { Komponen yang ditetapkan }}{\text { Jumlah Komponen Total }} \times 100 \%
$$

$$
\text { Persentase }=2 / 3 \times 100 \%=67 \%
$$


Dengan demikian, Edukasi Enggang Gading telah menerapkan manajemen terhadap sumber daya lingkungan sebesar $67 \%$ sebagai bagian kedua dari pariwisata berkelanjutan di bidang manajemen sumber daya lingkungan.

3). Minimalisir Dampak Kegiatan Wisata, Data - daya dan informasi yang diperoleh di lapangan menunjukan Edukasi Enggang Gading telah menerapkan upaya minimalisir dampak kegiatan wisata. Menurut World Tourism Organization (WTO), minimalisir dampak kegiatan wisata terdiri dari beberapa komponen, yaitu : manajemen limbah padat, manajemen limbah cair, manajemen infrastruktur dan pencegahan terhadap kerusakan spesies. Untuk itu tingkat presentase dari penerapan minimalisir dampak kegiatan wisata di Eduwisata Enggang Gading, adalah:

\section{Persentase $=\underline{\text { Komponen yang ditetapkan } \times 100 \%}$ Jumlah Komponen Total}

$$
\text { Persentase }=3 / 4 \times 100 \%=75 \%
$$

Dengan demikian, Eduwisata Enggang Gading telah menerapkan upaya minimalisir dampak kegiatan wisata sebesar 75\% sebagai bagian terakhir dari pariwisata berkelanjutan di bidang lingkungan fisik.

Berdasarkan ketiga komponen di atas,presentase rata - rata dari penerapan wisata berkelanjutan dalam aspek lingkungan fisik adalah :

1. Perlindungan Terhadap Aset Lingkungan $=67 \%$

2. Manajemen Terhadap Sumber Daya Lingkungan $\quad=67 \%$

3. Minimalisir Dampak Kegiatan Wisata $\quad=75 \%$
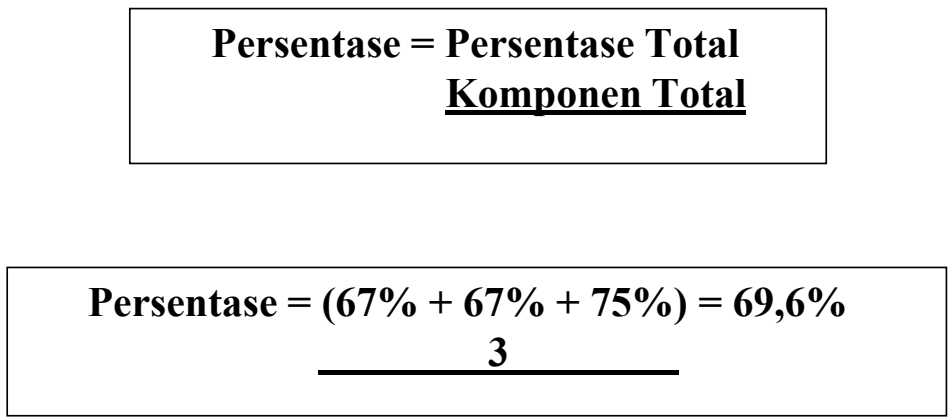

Dengan demikian, Eduwisata Enggang Gading telah menerapkan perinsip pariwisata berkelanjutan dalam aspek lingkungan fisik sebesar $69,6 \%$. 


\section{Aspek Sosial Budaya}

a. Pengorganisasian, tahap pengorganisasian, pengelola Eduwisata Enggang Gading merencanakan program-program yang merupakan penjabaran dari ketiga misi terakhirnya, yaitu: 1) membangun solidaritas antar masyarakat setempat; 2) memgembangkan nilai-nilai luhur dan seni budaya Dayak Kenyah; dan 3) menghargai serta ikut bertanggung jawab dalam memelihara budaya dan suku lainnya.

b. Interpetasi, Pengelola Eduwusata Enggang Gading menyusun beberapa upaya dan petunjuk teknis yang ssuai dengan kaidah sosial budaya.

Tabel 7

Teknis Program Kerjasama Dalam Aspek Sosial Budaya

\begin{tabular}{|c|c|}
\hline Upaya & Petunjuk Teknis \\
\hline \multirow{2}{*}{$\begin{array}{l}\text { Menyangga Aset } \\
\text { Budaya }\end{array}$} & Menampilkan kebiasaan umum masyarakat Dayak Kenyah \\
\hline & $\begin{array}{l}\text { Mengangkat nilai-nilai budaya Dayak Kenyah yang mulai } \\
\text { memudar }\end{array}$ \\
\hline \multirow{2}{*}{$\begin{array}{l}\text { Mendorong } \\
\text { Partisipasi } \\
\text { Masyarakat }\end{array}$} & Menetapkan peran sesuai divisi \\
\hline & $\begin{array}{c}\text { Menerapkan sistem job rolling untuk tugas-tugas sifatnya } \\
\text { umum }\end{array}$ \\
\hline \multirow{3}{*}{$\begin{array}{l}\text { Membangun } \\
\text { Interaksi } \\
\text { Masyarakat }\end{array}$} & Menanamkan kebiasaan gotong royong dan saling berbagi \\
\hline & $\begin{array}{l}\text { Membangun jiwa respek terhadap } \\
\text { nilai-nilai budaya dan kebiasaan suku lainnya }\end{array}$ \\
\hline & $\begin{array}{l}\text { Membangun jiwa respek terhadap pengunjung dan tamu } \\
\text { lainnya }\end{array}$ \\
\hline
\end{tabular}

c. Aplikasi

1). Menyangga Aset Budaya, Presentase penyanggaan aset budaya di Eduwisata Enggang Gading adalah :

$$
\begin{gathered}
\text { Persentase }=\underset{\text { Komponen yang diterapkan } \times 100 \%}{\text { Jumlah komponen Total }} \\
\text { Kumlah }
\end{gathered}
$$

$$
\text { Persentase }=2 / 2 \times 100 \%=100 \%
$$

Dengan demikian, Eduwusata Engagang Gading Telah menerapkan upaya penyanggan aset budaya di bidang sosial budaya.

2). Mendorong Presentase Masyarakat

$$
\text { Persentase }=\frac{\text { Komponen vang diterapkan }}{\text { Jumlah komponen Total }} \text { 100\% }
$$




$$
\text { Persentase }=2 / 2 \times 100 \%=100 \%
$$

Dengan demikian, Eduwisata Enggang Gading telah melibatkan partisipasi masyarakat sebesar $100 \%$ sebagai bagan kedua daripariwisata berkelanjutan di bidang sosial budaya.

3). Pola Interaksi Masyarakat

$$
\text { Persentase }=\frac{\text { Komponen vang diterapkan }}{\text { Jumlah komponen Total }} \text { 100\% }
$$

$$
\text { Persentase }=2 / 3 \times 100 \%=67 \%
$$

Dengan demikian, pola interaksi masyarakat Enggang Gading baru mencapai presentase sebesar $67 \%$ sebagai bagian terakkhir dari pariwisata berkelanjutan di biang sosial budaya.

Berdasarakan ketiga komponen diatas, persentase rata - rata dari penerapan wisata berkelanjutan dalam aspek sosial budaya adalah :

1. Penyangga Aset Budaya $=100 \%$

2. Partisipasi Masyarakat $=100 \%$

3. Pola Interaksi Masyarakat $=67 \%$

\section{Persentase $=$ Persentase Total $\underline{\text { Komponen Total }}$}

$$
\begin{gathered}
\text { Persentase }=\frac{(100 \%+100 \%+67 \%)}{3} \\
=89 \%
\end{gathered}
$$

Dengan demikian, Eduwisata Enggang Gading telah menerapkan prinsip pariwisata berkelanjutan dalam aspek sosial budaya sebesar $89 \%$.

\section{Aspek Ekonomi}

a. Pengorganisasian, pengelola Eduwisata Enggang Gading merencanakan program program yang dinilai mampu menopang perekonomian masyarakat sekitar.

b. Interpretasi,pengelola Eduwisata Enggang Gading menyusun berbagai petunjuk teknis yang sesuai dengan kaidah ekonomi. 
Teknis Program Kerja Dalam Aspek Ekonomi

\begin{tabular}{|c|c|}
\hline Atraksi & Deskripsi \\
\hline \multirow{2}{*}{$\begin{array}{c}\text { Mengadakan } \\
\text { Program } \\
\text { Ketenagakerjaan }\end{array}$} & Menyediakan lapangan pekerjaan \\
\cline { 2 - 2 } & Memberdayakan SDM \\
\hline \multirow{3}{*}{$\begin{array}{c}\text { Mengadakan } \\
\text { Kebijakan Upah }\end{array}$} & Meninjau efektivitas kinerja \\
\cline { 2 - 2 } & Menyediakan upah tetap \\
\cline { 2 - 2 } & Menambah upah dari hasil penjualan \\
\hline
\end{tabular}

Sumber : Olahan Peneliti, 2019

c. Aplikasi

1). Menyediakan Program Ketenagakerjaan

$$
\begin{gathered}
\text { Persentase }=\underset{\text { Komponen yang diterapkan } \times 100 \%}{\text { Jumlah komponen Total }} \\
\text { Kum }
\end{gathered}
$$

$$
\text { Persentase }=2 / 3 \times 100 \%=67 \%
$$

Dengan demikian, prestasi ketenagakerjaan di Eduwisata Enggang Gading baru mencapai persentase $67 \%$ sebagai bagian dari pariwisata berkelanjutan di bidang ekonomi.

2). Mengadakan Kebijakan Upah

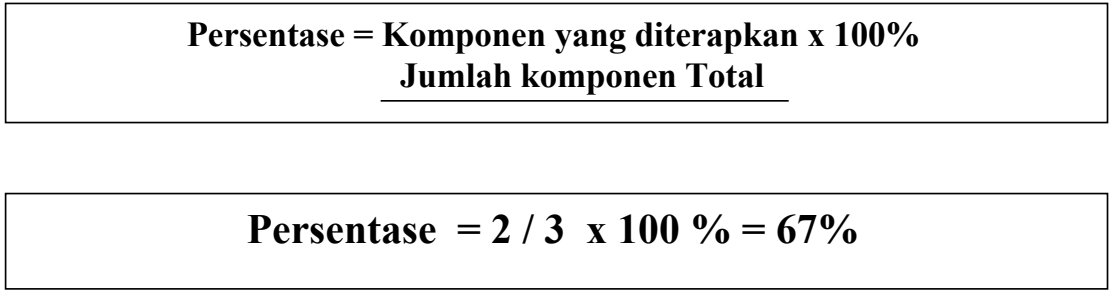

Dengan demikian, kebijakan upah di Eduwisata Enggang Gading baru mencapai presentase sebesar 67\% sebagai bagian terakhir dari pariwisata berkelanjutan di bidang ekonomi.

Berdasarkan kedua komponen diatas, presentase rata - rata dari penerapan wisata berkelanjutan dalam aspek ekonomi adalah :

$$
\begin{array}{ll}
\text { 1. Ketenagakerjaan } & =67 \% \\
\text { 2. Pendapatann } & =67 \%
\end{array}
$$




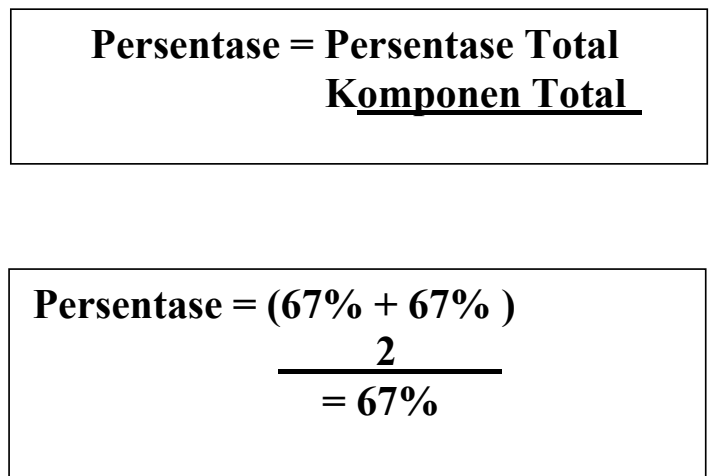

Dengan Demikian, Eduwisata Enggang Gading telah menerapkan prinsip pariwisata berkelanjutan dalam aspek ekonomi sebesar $67 \%$.

\section{SIMPULAN}

Hasil penelitian dan pembahasan menunjukkan bahwa Eduwisata Enggang Gading telah menyajikan atraksi wisata yang cukup beragam. Keragaman tersebut dapat dilihat dari pengelompokkan tema wisata menjadi dua kategori umum, yaitu wisata alam dan wisata budaya. Meski tergolong sebagai sebuah destinasi yang baru, Eduwisata Enggang Gading telah menyajikan lima jenis atraksi bertema alam dan tujuh jenis atraksi bertema budaya. Namun sejauh ini, atraksi-atraksi di Eduwisata Enggang Gading belum berjalan dengan baik karena dua faktor yaitu kunjungan minim dan jumlah SDM tetap yang masih terbatas. Berdasarkan hasil pengamatan dan informasi di lapangan, peneliti menyimpulkan bahwa atraksi wisata yang disajikan di Eduwisata Enggang Gading belum berjalan dengan efektif. Sedangkan implementasi pariwisata berkelanjutan di Eduwista Enggang Gading, telah menerapkan pariwisata berkelanjutan dengan presentase dari aspek pariwisata berkelanjutan sebagai berikut, aspek lingkungan fisik sebesar 69\%, aspek budaya sebesar $89 \%$ dan aspek ekonomi sebesar $67 \%$ dari semua nilai persentase tersebut tergolong baik.

\section{DAFTAR PUSTAKA}

Abdilah, A. B. (2016). Dampak Pengembangan Pariwisata Terhadap Kehidupan Masyarakat Lokal di Kawasab Wisata : Studi Pada Masyarakat Sekitar Wisata Wendit. Jurnal Admidtrasi Bisnis, 75 - 76.

Burns, L. e. (2010). Heritage Tourism Handbook: A How-To-Guide for Georgia. Washington: Georgia.

Fitriyani. (2015). Peran Pemuda Dalam Mengembangkan Eco Edu Wisata Mangrove Dan Implikasinya Trhadap Ketahanan Lingkungan Daerah. Jurnal Ketahanan Nasional, $21(2), 130$.

Ghony. (2012). Metode Penelitian Kuantitatif. Jakarta: Ar-Ruzz Media.

II, A. D. (2018). Road map and Program Prioritas Pembangunan Kepariwisataan Jawa dan Kalimantan. Laporan Akhir. 
Lenjau, S. (2019). Peduli Wisata Enggang Gading: Sebuah Pengantar Perdana. Samarinda.

Malihah, E. \&. (2014). Tourism Education and Edutourism Development Sustainable Tourism Development Perspevtive in Education. Converence Paper.

Mawardi, R. N. (2018). PENGARUH PRODUCT KNOWLEDGE TERHADAP PURCHASE INTENTION (Survei pada Pengunjung Toko Buku UB Press, Kota Malang). Jurnal Administrasi Bisnis (JAB)|Vol. 55 No. 3, 41-47.

Muljadi, A. J. (2016). Kepariwisataan dan Perjalanan. Jakarta: Raja Grafindo Persada.

Noor, A. A. (2016). Konsep Pengembangan Pariwisata Berkelanjutan di Kampung Buyut Cipageran (Kabuci) Kota Cimahi. Industrian Research, Workshop dan National Seminar.

Nugroho, I. (2015). Ekowisata dan Pembangunan Berkelanjutan. Yogyakarta: Pustaka Pelajar.

Pusparini, G. d. (2018). Program Pelestarian Budaya Edutourism Pada Taman Baca Masyarakat Eco Bambu Cipaku. Jurnal Library and Information Science, 6.

Resmawa, I. N. (2017). Pengaruh Brand Image dan Product Knowledge terhadap Purchase Intention dengan Green Price sebagai Moderating Variabel pada Produk the Body Shop di Surabaya. Aplikasi Manajemen, Ekonomi dan Bisnis, Vol. 1, No. 2.

Samarinda, B. K. (2017). Kecamatan Samarinda Utara Dalam Angka. Samarinda: BPS Kota Samarinda.

Satori, D. \&. (2013). Metodelogi Peenelitian Kualitatif. Bandung: Alfabeta.

Subadra, I. N. (2006). dAMPAK konomi, sosialbudaya,dan lingkungan pengembangan desa wisata di Jatileuwih - Tabanan. Jurnal Manajemen Pariwisata, 5 (1), 50.

Suharso, B. (2015). Pengembangan Pariwisata Berkelanjutan Melalui Ekowisata . Makalah focus, 7.

UNWTO. (2004). Indicators of Sustainable Development for Tourism Destinations. Madrid: Calle Caitan Haya.

Yoeti, O. A. (2014). Pengantar Ilmu Pariwisata. Bandung: Angkasa.

Yusufadisyukur, E. O. (2017). Pariwisata: Sinergi Pengembangan Wisata Kuliner dan Agrowisata. 